\title{
Proteomic Analysis of Cassava Mosaic Virus (CMV) Responsive Proteins in Cassava Leaf
}

\author{
Raghu Duraisamy ${ }^{1 *}$, Senthil Natesan ${ }^{1}$, Raveendran Muthurajan ${ }^{1}$, \\ Karthikayan Gandhi², Pugalendhi Lakshmanan ${ }^{3}$, Janavi Gnanaguru Janaky ${ }^{3}$, \\ Nageswari Karuppusamy ${ }^{4}$ and Mohan Chokkappan ${ }^{5}$
}

${ }^{1}$ Centre for Plant Molecular Biology and Biotechnology, Tamil Nadu Agricultural University, Coimbatore, India

${ }^{2}$ Centre for Plant Protection Studies, Tamil Nadu Agricultural University, Coimbatore, India

${ }^{3}$ Faculty of Horticulture, Tamil Nadu Agricultural University, Coimbatore, India

${ }^{4}$ Tapioca and Castor Research Station, Tamil Nadu Agricultural University, Yethapur, India

${ }^{5}$ Central Tuber Crops Research Institute, Trivandrum, Kerala, India

*Corresponding author

\section{Keywords}

Cassava leaf protein, CMV, 2DPAGE, MALDITOF

Article Info

Accepted:

20 March 2019

Available Online:

10 April 2019

\section{A B S T R A C T}

Proteomics is becoming an increasingly important tool for the study of many different aspects of plant functions, such as investigating the molecular processes underlying hostpathogen interaction, plant physiology, development and differentiation. Cassava mosaic disease (CMD), caused by cassava mosaic virus (CMV), is the most serious disease in cassava. However, the molecular mechanisms underlying CMD in cassava during CMV infection is not yet clearly understood. The current study determined and identifies the differentially expressed proteins from cassava leaves during the infection of CMV viz., Indian Cassava mosaic virus (ICMV) and Sri Lankan Cassava Mosaic Virus (SLCMV). 2D gel electrophoresis was used to identify the cassava responsive proteins during the virus infection and the differentially expressed proteins were analysed by matrix-assisted laser desorption/ionization-time-of-flight (MALDI-TOF) mass spectrometry. There are 19 proteins were differentially expressed in cassava leaves by CMV infection. Among them 18 were giving good spectra by MALDI-TOF mass spectrometry. Analysis of Peptide Mass Fingerprint (PMF) data of these 18 proteins revealed the identity of the differentially expressed proteins, which suggest their importance and relevance on plant growth and development, and defence. This work paves the way towards a comprehensive analysis of CMV infection of cassava. Identification of the differentially expressed proteins by their sequence homology to known proteins suggests a possible direct or indirect role on plant defence during CMV infection. This study revealed the differentially expressed proteins, expressed during interaction between cassava and CMV that might play important roles either in viral pathogenesis or resistance. 


\section{Introduction}

Cassava (Manihot esculenta Crantz) is a food security perennial crop of the Euphorbiaceae family, which originated in South America and reached Africa and Asia during the 16th and 17th centuries. Currently, cassava is extensively cultivated as an annual crop in tropical and subtropical regions for their rich source of carbohydrates (85\%) and protein (1$2 \%$ ) for human food in the world and the world's sixth food crop for more than 800 million people (Liu et al., 2011; Howeler et al., 2013). It has a high growth rate under optimal conditions and the tuberous roots as well as the leaves are used as human food, animal feed and industrial products (Mann, 1997; El-Sharkawy, 2004; Sheffield et al., 2006; Gbadegesin et al., 2008). Although cassava roots and leaves combine high energy, protein and high levels of some vitamins, minerals and dietary fibre (Prathibha, 1995; Bradbury, 1998) and high productivity under drought and poor soil conditions, it is highly susceptible to various diseases, post-harvest physiological deterioration (Gegios et al., 2010; Stephenson et al., 2010; Vanerschuren et al., 2014; Patil et al., 2015; Urrota et al., 2016). Cassava improvement programs are focused on addressing these constraints but are hindered by their high heterozygosity, difficulty in synchronizing flowering, low seed production and a poor understanding of the physiology of this plant (Ceballos et al., 2004)

The yield of cassava can be reduced to up to $100 \%$ due to cassava mosaic disease (CMD), which is caused by various isolates of cassava mosaic geminiviruses (CMGs). In India, two CMGs namely Indian Cassava mosaic virus (ICMV) and Sri Lankan Cassava Mosaic Virus (SLCMV) are the causal agent of CMD in cassava. Due to its less importance, the research to improve cassava has lagged behind that of other crops such as rice, wheat, maize, and potatoes. Therefore, only relatively minor increases in cassava's productivity have been obtained.

Analysis of proteins expressed in cassava leaf tissues will provide a better understanding of the constitutive differences controlling the plant's growth, development, and defences during CMV infection. Furthermore, the recent molecular biological techniques of differential expression of genes or proteins during plant-pathogen interaction can be used as a powerful tool to dissect the molecular mechanism underlying the susceptibility of different cassava cultivars to CMV infection. In recent years, differential expression of eukaryotic proteins has been employed as a research approach in many laboratories to detect proteins that change in response to pathogen ingress. The main advantage of this technique is that it permits the simultaneous identification of up and down regulated proteins and may serve as genetic and diagnostic markers, as well as providing insights into the underlying mechanisms of disease incidence. Most of the previous studies focused on the effects of environmental factors and physiology of cassava in relationship to crop yield (extensively reviewed in El-Sharkawy, 2004). At the molecular level, there are few reports on genes and proteins that may play important roles in controlling cassava storage root formation and yield. Yet, there has not been any report in the literature on molecular and biochemical investigation of leaf genes or proteins of cassava during CMV infection.

Particularly, to date, there have been very few papers in the literature about proteomic analysis on storage root (Souza et al., 1998; Cabral and Carvalho, 2001; De Souza et al., 2002; Shewry, 2003; Sheffield et al., 2006), somatic embryos, plantlets and tuberous root (Li et al., 2010). However, a proteome analysis of cassava leaf during growth and 
development was reported earlier by Mitprasat et al., (2011).

This study represents the proteomic analysis of cassava leaves during CMV infection. To further fulfil the lacking knowledge in the literature, leaf proteins that were differentially expressed during CMV infection of cassava were examined using a proteomic approach. Two-dimensional (2-D) gel electrophoresis combined with mass spectrometry revealed a number of candidate proteins that are differentially expressed between CMVinfected and non-infected healthy cassava leaves.

\section{Materials and Methods}

\section{Genetic materials}

Cassava cultivar $\mathrm{H} 226$ was obtained from the germplasm pool, Tapioca and Castor Research Station (TCRS), Yethapur, Tamil Nadu Agricultural University (TNAU). The healthy (meristem-derived virus free) and CMV infected (artificially inoculated meristem-derived) cassava leaves were used as the protein source in this study.

\section{Cassava meristem culture}

The virus-free healthy cassava plants were developed through apical meristem culture at Faculty of Horticulture, TNAU as described previously (Raghu et al., 2011). All the meristem-derived plants were fertilized with Hoagland solution (Hoagland and Arnon 1950) and the absence of CMV was detected by Polymerase chain reaction (PCR) using CMGs degenerate primers (Forward: 5'- TAA TAT TAC CKG WKG VCC SC -3'; Reverse: 5'- TGG ACY TTR CAW GGB CCT TCA CA -3') (Deng et al., 1994) with suitable controls. The PCR conditions and mixes were as described previously by Raghu et al., (2013).

\section{Whitefly-vector based transmission of CMV}

In this study we used a mixture of two viruses belonging to CaMV group viz., SLCMV and ICMV for studying the host pathogen interaction between CMV and cassava cv. H226 A general method for CMV acquisition and transmission in meristem-derived healthy cassava plants was employed as described earlier by Antony et al., (2009) with slight modifications (Raghu et al., 2011). The confirmation of SLCMV and ICMV infection in whitefly inoculated cassava plants was done by PCR using CMV replicase specific primers (Forward: 5'-TGT GAC CTT GAT TGG CAC CTG-3'; Reverse: 5'-CTC GAC GAG TGG TTT CAC GA-3' for ICMV and Forward: 5'-TAG CTG CCC TGT GTT GGA C-3'; Reverse: 5'-TGA GAA ACC CAC GAT TCA GA-3' for SLCMV). Reaction conditions were essentially those of Sambrook et al., (1989). PCR parameters were $94^{\circ} \mathrm{C}$ for 2 min then 40 cycles of $1 \mathrm{~min}$ at $94^{\circ} \mathrm{C}, 1 \mathrm{~min}$ at $63^{\circ} \mathrm{C}$ and $1 \mathrm{~min}$ at $72^{\circ} \mathrm{C}$, followed by the final extension of $10 \mathrm{~min}$ at $72^{\circ} \mathrm{C}$.

\section{Proteomic analysis}

\section{Sampling}

Three biological replicates of leaf tissues were collected from healthy (control) and CMV infected cassava plants (Figure 1) and immediately transferred into liquid nitrogen $\left(\mathrm{LN}_{2}\right)$ and stored at $-80^{\circ} \mathrm{C}$ until further use.

\section{Protein extraction}

Triplicate samples of frozen cassava leaf tissues were ground finely in a mortar cooled with Liquid Nitrogen and suspended in 10\% $(\mathrm{w} / \mathrm{v})$ trichloroacetic acid in acetone with $0.07 \%(\mathrm{w} / \mathrm{v})$ dithiothreitol (DTT) at $-20^{\circ} \mathrm{C}$ for $1 \mathrm{~h}$, followed by centrifugation for $15 \mathrm{~min}$ at 
35,000 g. The pellets were washed with icecold acetone containing $0.07 \%$ DTT, incubated at $-20^{\circ} \mathrm{C}$ for $1 \mathrm{~h}$, and centrifuged again at $4^{\circ} \mathrm{C}$. This step was repeated thrice and the final pellets were lyophilized. The powder was then solubilized in lysis buffer (at $37^{\circ} \mathrm{C}$ ) and the protein content was determined by the Bradford method (Bradford, 1976; Salekdeh et al., 2002; Jagadish et al., 2010).

\section{D gel}

Equal amounts of protein $(150 \mu \mathrm{g})$ from healthy and CMV infected samples were separated by Two-dimensional polyacrylamide gel electrophoresis (2DPAGE), as described by Yan, et al., (2005). In the first dimension, IPG strips (BioRad Laboratories, USA) of $17-\mathrm{cm}$ length and $\mathrm{pH}$ 4-7 were used. Electrophoresis was carried out at $400 \mathrm{~V}$ for $1 \mathrm{~h}$, followed by $1000 \mathrm{~V}$ for 1 $\mathrm{h}$ and $2950 \mathrm{~V}$ for $24 \mathrm{~h}$. After IEF, the proteins were separated by SDS-PAGE in the second dimension using 13\% polyacrylamide gels (Salekdeh et al., 2002). The gels were stained by silver staining method (Blum et al., 1987). For each biological replicate, one set of gels with high resolution, run at different times, was selected for further analysis. The relative abundance of protein spots was quantified with Melanie III (GeneBio, Geneva, Switzerland), after silver staining the gels, and scanned with a densitometer (GS-700, Bio-Rad).

\section{Matrix-assisted laser desorption/ionization- time of flight mass spectrometry (MALDI- TOF MS) and database searching}

Selected spots were excised from preparative gels (stained with AgNO3) (Salekdeh et al., 2002) and extracted by an addition of $10 \mu 1$ of the extraction buffer, followed by an addition of 10-15 $\mu \mathrm{l}$ of acetonitrile. Pooled extracts were dried in a lyophilizer (SFDSN06, Samwon Freezing Engineering Co., Busan) and the extracts were re-dissolved in $1 \mu 1$ of extraction buffer and $1 \mu$ l of matrix solution ( $\alpha$-acyano-4-hydroxycinnamic acid, HCCA) and targeted onto a MALDI-TOF plate. After drying the samples completely onto the targeting plate, MALDI-TOF/MS was conducted using a Voyager-DE STR mass spectrometer (Applied Biosystems, Franklin Lakes, NJ, USA) equipped with delay ion extraction. Mass spectra were obtained over a mass range of 808-2705 Da. For identification of proteins, the peptide mass fingerprinting data were used to search against the Swissprot database using the Mascot program (http://www.matrixscience.com). The following parameters were used for database searches: taxonomy, viridiplantae, cleavage specificity, trypsin with one missed cleavage allowed; peptide tolerance of $100 \mathrm{ppm}$ for the fragment ions; and allowed modifications, Cys Carbamidomethyl (fixed), and oxidation of Met (variable).

\section{Results and Discussion}

CMV responsive protein profiling in cassava leaves by $2 \mathrm{D}$-gel analysis

Comparison of mRNA or proteins isolated from target tissues of infected and healthy (control) (Figure 1) plants can provide information on the biochemical and molecular changes associated with CMV infection of cassava cv.H226. Thus, a proteomic analysis could be a powerful approach to identify responsive proteins associated to a biotic stress, such as pathogen infection. In this study, we adopted a proteomic strategy using 2-D gel electrophoresis to understand the molecular changes in cassava leaves infected by CMV versus that healthy cassava $\mathrm{cv}$. H226.

CMV was artificially inoculated in healthy (meristem-derived) plants of cassava cv.H226 by whiteflies (Bemisia tabaci) and leaf tissues 
were collected at after 21 days post inoculation for the proteomic analysis. Proteins were extracted from leaves using the TCA precipitation method and separated by 2-D gel electrophoresis as previously described by Yan et al., (2005). Silver staining of cassava leaf proteins separated by 2-D gel electrophoresis allowed the detection of around 300-350 spots (Figure 2). Comparison of 2-D gel electrophoretic pattern of leaf proteins between infected and healthy cassava leaves revealed the differential expression of nineteen protein spots (Table 1). Among the 19 protein spots that were differentially expressed, $11(58 \%)$ were found to be up-regulated (Figure 3a) and 8 (42\%) were found to be down-regulated by $\mathrm{CMV}$ infection of cassava cv. H226.

\section{Analysis of differentially expressed proteins of cassava during CMV infection}

Among the 19 differentially expressed protein spots, only 18 protein spots resulted in good spectra by MALDI-TOF while spot \#1 did not. PMF data analysis of the eighteen protein spots derived by MALDI-TOF mass spectrometry using MASCOT search algorithm showed homology to ribosomal protein 4 , chaperone protein DNAj, putative cytochrome c oxidase subunit II PS17, ATP binding cassette transporter, maturase $\mathrm{K}$, oxygen-evolving enhancer protein 1, ascorbate peroxidase APX2, ATP synthase beta subunit, protein kinase-coding resistance protein, 2-oxoglutarate-Fe(II)-dependent oxygenase domain containing protein, component of cytosolic $80 \mathrm{~S}$ ribosome, $40 \mathrm{~S}$ small subunit and NADP-dependent sorbitol6-phosphate dehydrogenase.

Protein spot \#17 and \#6 have the higher (6.730) and lower (0.203) abundance ratio, respectively. The average spot abundance ratio of down regulated proteins was 0.482 and that of up-regulated proteins was 3.556.
Because of limited genome information of cassava in database, only 4 differentiallyexpressed protein spots (\#10, \#13, \#15 and \#16) were identified by the peptide mass fingerprint analysis. The differential expression of proteins in spots \#10, \#13, \#15 and \#16 was significant, while the remaining proteins were found to be marginally significant (Table 1). We attribute the somehow low number to differentially expressed proteins that have significant Mascot scores to the limited genome information of cassava in the database.

The proteomic analysis conducted here showed that the differentially expressed proteins identified which are either up or down regulated during CMV infection of cassava cv. H226 may play important roles related to plant growth, development and the defense against virus infection.

The present study is the second report on proteomics of cassava and the first one studying the cassava leaf proteome during CMV infection. Our aim was to identify major leaf proteins that exhibit differential expression pattern during CMD, which is caused by CMV in cassava plants. Biotic and abiotic stress results in alterations of plant homeostasis, including reduced photosynthetic rate and ionic imbalance. Induction of disease tolerance in plants involves a complex network of signal perception, amplification, and transduction which might include protein phosphorylation cascades, ion fluxes, oxidative stress and generation of secondary signals and activation of various genes involved in disease tolerance. Gene and protein expression profiling has become an important tool to investigate how an organism responds to environmental changes. Yet, there has not been any report in the literature on molecular and biochemical investigation of leaf genes or proteins involve in CMD of cassava. 
Particularly, to date, there have been very few papers in the literature about proteomic analysis of cassava (Cabral and Carvalho 2001; Sheffield et al., 2006; Li et al., 2010; Mitprasat et al., 2011). To further fulfil the lacking information in the literature, leaf proteins that are differentially expressed during CMD in cassava were examined in this study using a proteomic approach.

Recent whole genome expression profiling techniques such as microarrays and proteomics have been used to dissect the molecular mechanism(s) leading to the development of a phenotype. Differential expression of genes or proteins in storage root (Cabral and Carvalho, 2001; De Souza et al., 2002; Sheffield et al., 2006), somatic embryos, plantlets and tuberous root (Li et al., 2010) and leaf (Mitprasat et al., 2011) during growth and development of cassava has been reported earlier. In this study, we adopted a proteomics strategy to understand the molecular changes in leaves of healthy and infected cassava (cv.H226) plants.

Silver staining of the cassava leaf proteins separated by 2-D gel electrophoresis allowed the detection of around 300-350 spots. Comparison of 2-D gel electrophoretic pattern of leaves proteins between healthy and infected plants revealed the differential expression of 19 protein spots (Table 1). Among the 19 differentially expressed proteins, eleven protein spots (\#3, \#4, \#5, \#7, $\# 10, \# 13, \# 14, \# 16$, \#17, \#18 and \#19) were found to be up-regulated and eight protein spots (\#1, \#2, \#6, \#8, \#9, \#11, \#12, and \#15) were found to be down-regulated in cassava plants cv.H226 during CMV infection. Analysis of PMF data coupled with MASCOT searches allowed the identification of eighteen proteins showing significant or marginally significant homology to known proteins. Most likely the fact that only 4 differentially expressed proteins had significant matches while the other 14 were marginally significant is due to at least in part to the limited genome information of cassava on the NCBI database. Cabral and Carvalho (2001) and De Souza et al., (2002) reported similar findings about proteins associated with storage root formation in cassava. Mitprasat et al., (2011) reported that around 39 spots, which were successfully identified by ion trap LC-MS/MS, were significantly altered $(\mathrm{P}=0.05)$ during week 4 to 8 of growth in cassava leaf proteomic analysis during plant development, from planting of stem cutting to storage root formation.

\section{Translational control}

The ribosome is a two-subunit ribonucleoprotein complex that catalyzes the peptidyl transferase reaction of polypeptide synthesis, an absolute requirement. Chang et al., (2005) characterized 251 Evolutionarily Conserved and Variable Proteins of cytosolic $80 \mathrm{~S}$ and $40 \mathrm{~S}$ ribosomes in Arabidopsis. The present study revealed that the up regulation of component of cytosolic $80 \mathrm{~S}$ ribosome and $40 \mathrm{~S}$ small subunit shows induced protein synthesis. This may be due to the expression of viral and plant proteins which are involved in host pathogen interaction.

\section{Metabolism related proteins}

The group of differentially expressed proteins which are involved in primary metabolism can also provide substrate for the synthesis of secondary metabolites. The 6 proteins identified from this group comprised: NADPdependent sorbitol-6-phosphate dehydrogenase (spot \#19), 2-oxoglutarate$\mathrm{Fe}(\mathrm{II})$-dependent oxygenase domain containing protein (spot \#17), cytochrome c oxidase (spot \#6), ATP synthase beta subunit (spot \#15), maturase K (spot \#9) and oxygenevolving enhancer protein 1 (spot \#12). 
Table.1 Abundance ratio and identity of induced proteins among cassava mosaic virus (CaMV) infected cassava leaves

\begin{tabular}{|c|c|c|c|c|c|c|c|c|c|c|}
\hline \multirow{2}{*}{$\begin{array}{l}\text { Sopt } \\
\text { ID }\end{array}$} & \multirow{2}{*}{$\begin{array}{l}\text { Up/Down } \\
\text { regulation }\end{array}$} & \multicolumn{2}{|c|}{ Experimental } & \multirow{2}{*}{$\begin{array}{l}\text { Abundan } \\
\text { ce ratio }\end{array}$} & \multirow[t]{2}{*}{ Coverage } & \multirow{2}{*}{$\begin{array}{l}\text { Mows } \\
\text { e score }\end{array}$} & \multicolumn{2}{|c|}{ Theoretical } & \multirow[t]{2}{*}{ Accession No } & \multirow[t]{2}{*}{ Putative Function } \\
\hline & & $\begin{array}{l}\mathrm{pI} \\
\text { value }\end{array}$ & Mass & & & & $\mathrm{pI}$ & MW & & \\
\hline$\# 2$ & Down & 4.65 & 12037 & 0.274 & 16 & 64 & 06.13 & 8300 & XP002322858 & Predicted protein (Populus trichocarlpa) \\
\hline$\# 3$ & Up & 4.6 & 15116 & 3.960 & 38 & 68 & 10.16 & 2197 & AAG52804 & Ribosomal protein 4 (Leptobryum stellatum) \\
\hline$\# 4$ & Up & 4.7 & 15707 & 3.790 & 46 & 53 & 09.69 & 8150 & XP002535156 & Chaperone protein DNAj, putative (Ricinus communis) \\
\hline$\# 5$ & Up & 5.4 & 17007 & 2.451 & 83 & 59 & 09.94 & 6615 & CAN63043 & Hypothetical protein (Vitis vinifera) \\
\hline \#6 & Down & 5.86 & 14503 & 0.203 & 100 & 43 & 09.62 & 1707 & P84733 & $\begin{array}{l}\text { Putative cytochrome c oxidase subunit II PS17 (Pinus } \\
\text { strobus) }\end{array}$ \\
\hline$\# 7$ & Up & 6.2 & 14514 & 4.070 & 33 & 67 & 9.53 & 3011 & XP002331812 & Predicted protein (Populus trichocarlpa) \\
\hline$\# 8$ & Down & 6.48 & 18301 & 0.290 & 35 & 60 & 9.11 & 1106 & XP002969857 & $\begin{array}{l}\text { ATP binding cassette transporter (Selaginella } \\
\text { moellendorffii) }\end{array}$ \\
\hline \#9 & Down & 4.2 & 31021 & 0.620 & 23 & 62 & 9.65 & 3240 & AEK35190 & maturase K, partial (chloroplast) (Datura stramonium) \\
\hline \#10 & Up & 4.72 & 20402 & 2.513 & 24 & 78 & 5.43 & 3307 & XP002951214 & Hypothetical protein (Volvox carteri f. nagariensis) \\
\hline \#11 & Down & 5.2 & 25106 & 0.590 & 60 & 55 & 10.10 & 5990 & XP002538199 & Conserved Hypothetical protein (Recinus communis) \\
\hline \#12 & Down & 5.34 & 25051 & 0.783 & 52 & 40 & 5.36 & 1066 & P84989 & $\begin{array}{l}\text { Oxygen-evolving enhancer protein } 1 \text { (chloroplast) } \\
\text { (Populus euphratica) }\end{array}$ \\
\hline \#13 & Up & 5.72 & 34003 & 2.240 & 46 & 93 & 5.73 & 1730 & AAX84679 & Ascorbate peroxidase APX2 (Manihot esculenta) \\
\hline$\# 14$ & Up & 5.86 & 34001 & 4.554 & 29 & 56 & 5.96 & 2544 & XP002985124 & Hypothetical protein (Selaginella moellendorffii) \\
\hline \#16 & $\mathrm{Up}$ & 6.07 & 60101 & 3.146 & 39 & 71 & 8.48 & 1618 & ACO25596 & $\begin{array}{l}\text { Protein kinase-coding resistance protein (Nicotiana } \\
\text { repanda) }\end{array}$ \\
\hline$\# 17$ & Up & 6.66 & 40008 & 6.730 & 19 & 61 & 5.89 & 3740 & NP190532 & $\begin{array}{l}\text { 2-oxoglutarate-Fe(II)-dependent oxygenase domain } \\
\text { containing protein (Arabidopsis thaliana) }\end{array}$ \\
\hline$\# 18$ & Up & 5.94 & 61017 & 2.580 & 38 & 62 & 10.18 & 2976 & XP002954017 & $\begin{array}{l}\text { Component of cytosolic } 80 \mathrm{~S} \text { ribosome and } 40 \mathrm{~S} \text { small } \\
\text { subunit (Volvox carteri f. nagariensis) }\end{array}$ \\
\hline$\# 19$ & Up & 6.85 & 38012 & 3.094 & 30 & 64 & 9.16 & 2852 & AAM77729 & $\begin{array}{l}\text { NADP-dependent sorbitol-6-phosphate dehydrogenase } \\
\text { (Prunus emarginata) }\end{array}$ \\
\hline
\end{tabular}

Spot ID, Experimental and theoretical pI, and MW correspond to the protein spot numbers indicated in Fig. 3. Proteins were identified by using the peptide masses from MALDI-TOF analysis, followed by data base search. Corresponding accession numbers for the identified proteins were obtained from NCBI (www.ncbi.nlm.nih.gov/) 
Fig.1 Healthy and Cassava mosaic virus (CaMV) infected cassava plants. a) Healthy uninfected shoots without mosaic symptoms; b) CaMV infected shoots showing pronounced mosaic pattern with narrow, severely twisted and distorted leaves

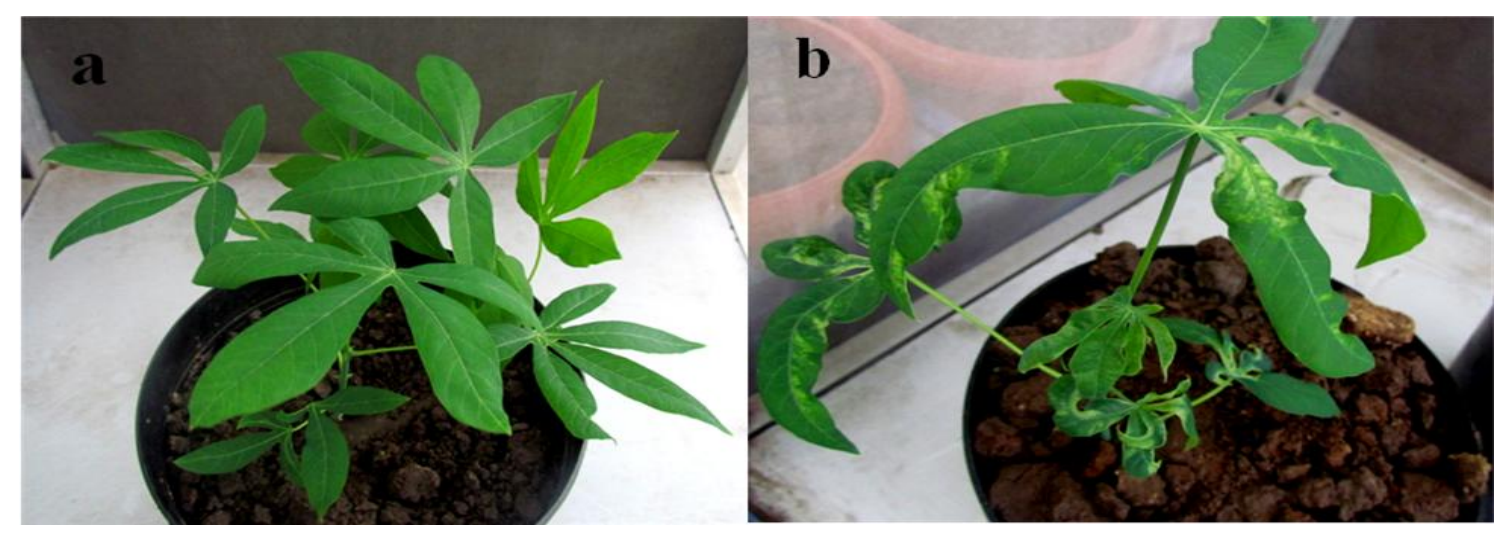

Fig.2 Two-dimentional gel electrophoresis analysis of total proteins extracted from the leaf tissue of cassava cv.H226 under control conditions. In the first dimension (IEF), $150 \mu \mathrm{g}$ of protein was loaded on a 17-cm IPG strip with a linear gradient of pH 4-7. In the second dimension, 13\% SDS-PAGE gels were used with molecular weight (Mr) standards. Proteins were visualized by silver staining.

The arrows indicate 19 proteins that showed up and down regulation and significantly under healthy and infected conditions

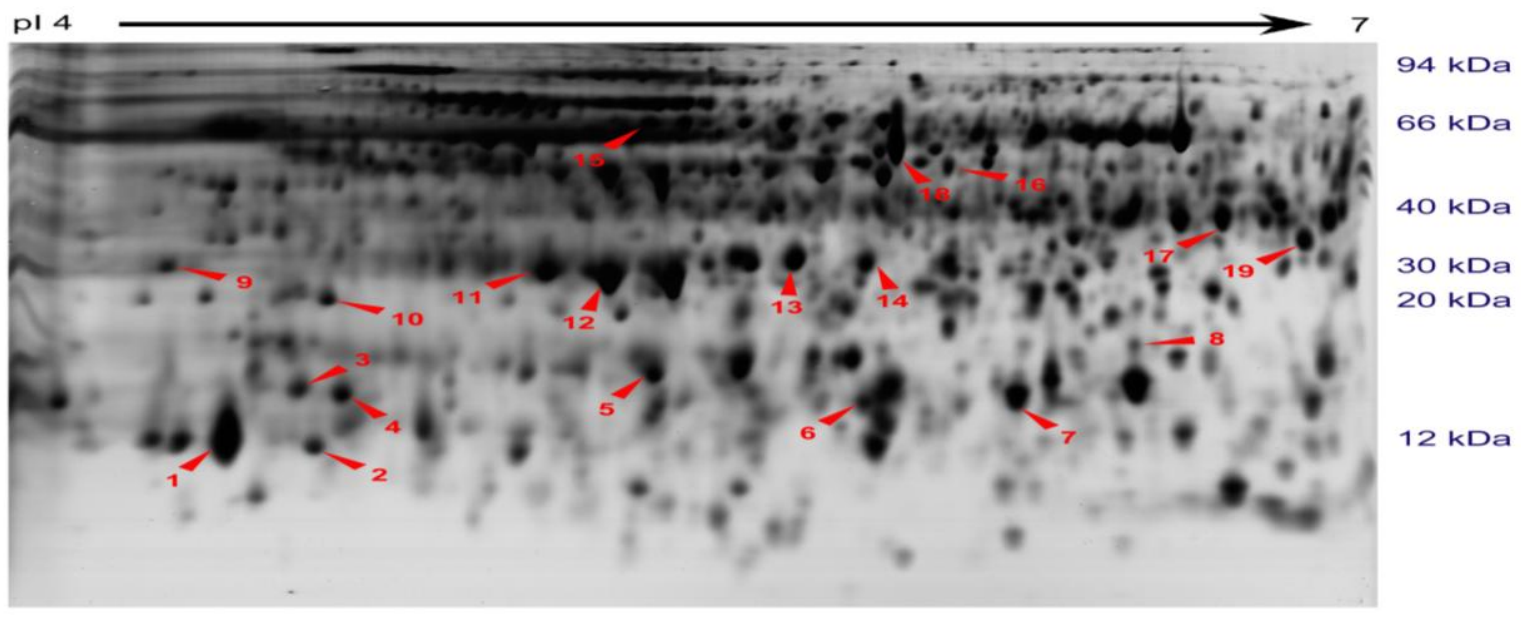


Fig.3 Magnified view of differentially expressed protein spots induced by cassava mosaic virus (CaMV) infection in cassava cv.H226 in a 2D gel electrophoresis. Up-regulated (A) and down-regulated (B) proteins are shown
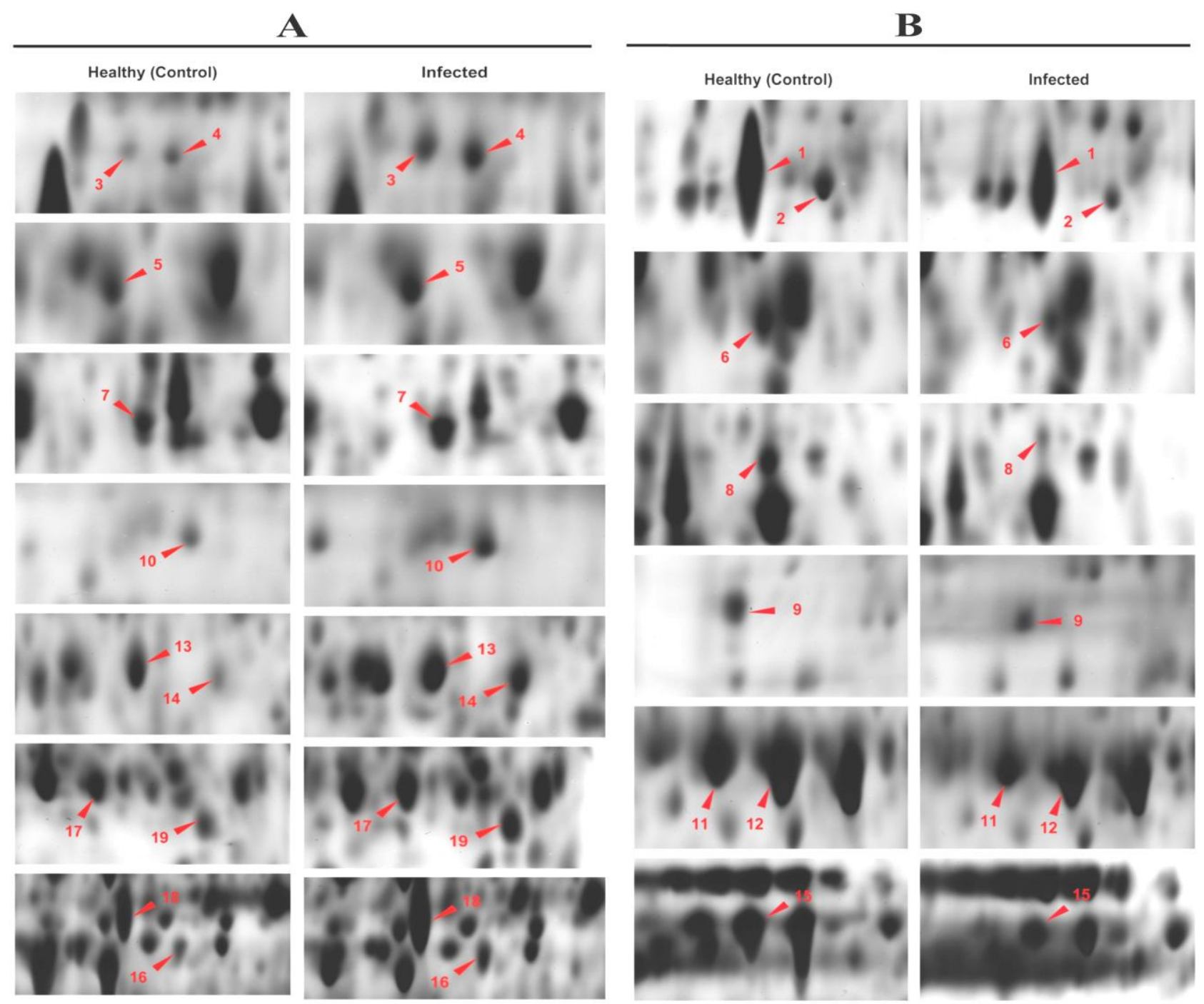
Sorbitol is known to be the primary transport product of photosynthesis. NADP-dependent sorbitol-6-phosphate dehydrogenase (spot \#19) is a key enzyme in sorbitol biosynthesis, where it catalyzes the NADPH-dependent reduction of glucose-6-phosphate to sorbitol6-phosphate (Herrera et al., 2010; Zhu et al., 2011).

Ferrous iron dependent oxygenases are a superfamily of enzymes that catalyse a wide range of reactions including hydroxylation, desaturation and oxidative ring closures. All the previous research studied 2-oxoglutarate (2OG) -Fe(II)-dependent oxygenase domain containing protein (spot \#17) have an absolute requirement for $\mathrm{Fe}$ (II) and catalyse a variety of two-electron oxidations, including hydroxylation, desaturation and oxidative ring closure reactions (Prescott, 1993; Prescott and John, 1996). In almost all cases, the oxidation of the 'prime' substrate is coupled to the conversion of $2 \mathrm{OG}$ into succinate and $\mathrm{CO} 2$. One of the oxygens of the dioxygen molecule is incorporated into succinate. In the case of desaturation reactions, the other dioxygenderived oxygen is presumably converted to water. In hydroxylation reactions, the partial incorporation of oxygen from dioxygen into the alcohol product occurs with significant levels of exchange of oxygen from water being observed (Baldwin et al., 1993; Lloyd et al., 1999).

The changing demands for energy and biosynthetic intermediates during plant growth and development are accommodated to a large extent by changes in the number and activity of mitochondria. Mitochondrial oxidative phosphorylation (OX-PHOS) in most eukaryotes is based on the sequential operation of five protein complexes termed complex I (NADH dehydrogenase), complex II (succinate dehydrogenase), complex III (cytochrome c reductase), complex IV (cytochrome c oxidase) and complex V (ATP synthase complex). The Cyt c oxidase complex is the terminal electron acceptor of the mitochondrial inner membrane respiratory chain. Evidence for possible activities of the cytochrome-linked systems in plants has been seen in: (a)oxidative systems in nonphotosynthetic tissues; (b) respiratory mechanisms in dark reactions in photosynthetic cells; and (c) light induced reactions (Smith, 1958).

Respiratory oxidative phosphorylation represents a central functionality in plant metabolism (Vanlerberghe and McIntosh, 1997; Plaxton and Podesta, 2006). Respiration rates, maximum activity of cytochrome $\mathrm{c}$ oxidase (protein spot \#6), and active mitochondrial number consistently decreased in plants infected with CMV. Plant growth during CMV infection also reduced cytochrome pathway activity and total mitochondrial ATP production.

ATP is a ubiquitous, energy-rich molecule of fundamental importance in living organisms. It is a key substrate and vital cofactor in many biochemical reactions and is thus conserved by all cells. Chivasa et al., (2011) identified subunits of the vacuolar and chloroplastic ATP synthase proteins as responsive to fumonisin B1 (FB1), with the great majority belonging to the mitochondrial $\mathrm{F}_{1} \mathrm{~F}_{0}$-ATP synthase machinery. In this study, the ATP synthase beta subunit (protein spot \#15) was down regulated that show that many biochemical reactions are affected during host-pathogen interaction between cassava and CMV. Similarly, Nwugo et al., 2013 also found that ATP synthase beta subunit got down regulated during Candidatus Liberibacter asiaticus infection in grapefruit plants. maturase $K$ is an invaluable gene present in chloroplast-encoded group II intron maturase (Muller et al., 2006; Barthet et al., 2007). RNA editing mechanisms previously reported in matK (Vogel et al., 1997; Tillich 
et al., 2005) may correct the reading frame in species with frame shift indels and premature stop codons and restore the codon identities needed to form the proper amino acids for function. Further, genome studies of the holoparasite Epifagus virginiana (Ems et al., 1995) and Adiantum capillus-veneris (Wolf et al., 2003) support that matK has a function in the plant. This putative enzyme critically impacts all chloroplast function including photosynthesis. Several chloroplast genes have light-induced expression (Klein and Mullet, 1990; Klein, 1991; Baumgartner et al., 1993). These genes are involved in two major activities of the chloroplast: photosynthesis and chloroplast development (Klein, 1991). Chloroplast development requires turning on protein translation in this organelle and increases the expression of all RNAs and proteins related to the translation machinery (Baumgartner et al., 1993). Maturase is needed for processing introns in order to generate the needed proteins and tRNAs for photosynthesis and/or the chloroplast translation machinery. However, maturase $\mathrm{K}$ (protein spot \#9), which is involved directly or indirectly in the regulation of plant development, was found to be down regulated during CMV infection in cassava in our study.

The present study showed the down regulation of oxygen-evolving enhancer protein 1 (protein spot \#12), which is involved in photosynthesis of Cassava. Similarly Nwugo et al., (2013) also observed that a down regulation of Oxygen-evolving enhancer (OEE) proteins during Candidatus Liberibacter asiaticus' (Las) infection which causes Huanglongbing (HLB) disease in grapefruit (Citrus paradisi). OEE proteins 1 and 2 are subunits of the oxygen-evolving system of PSII and are involved in stabilizing the Mn cluster (Pushkar et a., 2008). HLBaffected trees generally show leaf yellowing (chlorosis) which is likely due to a reduction in chlorophyll biosynthesis (Sagaram et al., 2009; Liao et al., 2012) and $\mathrm{Mg}$ is important in chlorophyll biosynthesis. Thus, a virusmediated reduction of the $\mathrm{Mg}$ content together with a reduction in $\mathrm{Fe}$ content of leaves of cassava plants could play a role in CMD-associated chlorosis.

\section{Molecular chaperones}

Virus proliferation depends on the successful recruitment of host cellular components for their own replication, protein synthesis and virion assembly. In the course of virus particle production, a large number of proteins are synthesized in a relatively short time, whereby protein folding can become a limiting step. Most viruses therefore need cellular chaperones during their life cycle. In addition to their own protein folding problems, viruses need to usurp or divert cellular resources, including host factors, away from their normal function (Witham and Wang, 2004) and interfere with cellular processes such as signal transduction, cell cycle regulation and induction of apoptosis in order to create a favourable environment for their proliferation and to avoid premature cell death (Mayer, 2005; Scholth of, 2005). Chaperones are involved in the control of these cellular processes and some viruses reprogram their host cell by interacting with them.

Molecular chaperones are thought to be involved as there are molecules present in anucleate sieve elements (SE) sap that are larger than the size exclusion limit (SEL) of plasmodesmata (PD) and movement can be bidirectional (Golecki et al., 1999; Oparka, 2004). It is thought that some proteins partially unfold and bind to another molecule that assists passage through the PD (Lucas, 1999; Ding et al., 2003). On the SE side, chaperone molecules would be required for the correct re-formation of the protein. 
Molecular chaperones may function by binding specifically to interactive protein surfaces exposed transiently during a cellular pro-cess, preventing them from undergoing incorrect interac-tions that might produce non-functional structures (Ellis, 1990).

Hsp70 chaperones, as central components of the cellular chaperone network, are frequently recruited by viruses. The chaperone function of Hsp 70 proteins in these events is regulated by members of the DnaJ-like protein (protein spot \#4) family, which occurs through direct interaction of different Hsp70 and DnaJ-like protein pairs that appear to be specifically adapted to each other. Bargen et al., (2001) identified DnaJ-like protein as a nonstructural protein encoded by the mRNA segment (NSm) of tomato spotted wilt virus (TSWV) interacting host proteins, implying an involvement of molecular chaperones during systemic spread of the virus by cell-tocell movement of nucleocapsid through modified plasmodesmata (PD) in tobacco and Arabidopsis.

\section{Signalling and disease resistance}

When plants are exposed to stressful environmental conditions, the production of Reactive Oxygen Species (ROS) such as $\mathrm{O}_{2}-$, $\mathrm{OH} \bullet$, and $\mathrm{H}_{2} \mathrm{O}_{2}$ increases and can cause significant damage to the cell components such as DNA, proteins and lipids (Thakur and Sohal, 2013). It is known that an excess of free oxygen radicals leads to programmed cell death (PCD) (Pellinen et al., 2002; Vranova et al., 2002). However, ROS are also utilized in various metabolic processes such as formation of lignin in the cell wall (Inze and Montagu, 1995), leaf and flower abscission, cell senescence, ripening of fruit and flowering (Mehlhorn et al., 1996). For the protection from oxidative damage, plant cells contain both oxygen radical detoxifying enzymes such as catalase, peroxidase, and superoxide dismutase, and nonenzymatic antioxidants such as ascorbate peroxidase and glutathioneS-transferase (Pnueli et al., 2003). These enzymes play a crucial role in the protection of plant cells from oxidative damage at the sites of enhanced ROS generation (Kuniak and Sklodowska, 2001). The cooperative function of these antioxidants plays an important role in scavenging ROS and maintaining the physiological redox status of organisms (Cho and Seo, 2005).

Antioxidant defenses, which can detoxify ROS, are present in plants (Mittler, 2002; Apel and Hirt, 2004; Foyer and Noctor, 2005). A major hydrogen peroxide detoxifying system in plant cells is the ascorbate-glutathione cycle, in which, ascorbate peroxidase (APX) enzymes play a key role catalyzing the conversion of $\mathrm{H}_{2} \mathrm{O}_{2}$ into $\mathrm{H}_{2} \mathrm{O}$, using ascorbate as a specific electron donor (Dąbrowska et al., 2007). Different APX isoforms are present in distinct subcellular compartments, such as chloroplasts, mitochondria, peroxisome, and cytosol (Caverzan et al., 2012). The APX responses are directly involved in the protection of plant cells against adverse environmental conditions. In the present study, the cell damage due to the CaMV infection was reduced by enhanced production of ascorbate peroxidase (protein spot \#13) in the leaf tissues.

Constant exposure to pathogen attack during their long evolutionary history of host plants has resulted in plant-pathogen coevolution. Interactions between plant pathogens and their host plants involve specific recognition and subsequent activation of a cascade of plant defense responses. Plant resistance gene $(R$-gene) plays an important role in plantpathogen recognition (Bendahmane, 2002). The protein encoded by the majority of the disease resistance genes present several highly conserved domains: nucleotide binding 
site (NBS), leucine-rich repeat (LRR), toll/interleukin receptor (TIR) domain, protein kinase (PK) domain etc. (Jones et al., 2001; Xiao et al., 2006). Intercellular signalling protein kinases that play a signalling role in the regulation of cellular energy metabolism. Their activity largely depends upon the concentration of cellular AMP which is increased under conditions of low energy or metabolic stress. Gao et al., (2010) expressed 73 resistant gene analogs (RGAs) of the protein kinase $(\mathrm{PK})$ class in tobacco with challenged inoculation with Tobacco mosaic virus (TMV) or the tobacco black shank pathogen (Phytophthora parasitica var. nicotianae). The expression of two RGAs of the PK class was induced by $P$. parasitica var. nicotianae. Infection by either TMV or $P$. parasitica var. nicotianae enhanced the expression of protein kinase genes coding resistance proteins. The present study shows that the up regulation of protein kinase-coding resistance protein (protein spot \#16) by CaMV should provide valuable information for cloning related resistance genes in cassava.

Previous reports have shown that the Arabidopsis ABC transporters (spot \#8) AtABCG36, AtABCG40, and NpPDR1 are involved in plant defense responses (Lipka et al., 2005; Kobae et al., 2006; Stein et al., 2006; Clay et al., 2009; Badri et al., 2012). For example, Badri et al., (2012) demonstrated the involvement of seven rootexpressed ATP-binding cassette (ABC) transporters (Atabcg36, Atabcg37, Atabcc5, Atabcf1, Atabcf3, Atnap5 and Atath10) in higher expression of defense genes by secreting phytoalexin in Arabidopsis thaliana after pathogen inoculation. Atabcg37 and Atabcc5 secreted higher levels of the phytoalexin camalexin, and Atabcg36 secreted higher levels of organic acids, specifically salicylic acid (SA).
This extensive study effectively provides a basis for further functional characterization of differentially expressed leaf proteins, which can help understand how biochemical processes in cassava leaves may be involved in cassava mosaic disease and dissect the molecular basis of host-pathogen interaction between cassava and cassava mosaic virus.

\section{Acknowledgements}

The authors would like to thank Rajiv Gandhi National Fellowship (RGNF) grant (No: F. 14-2 (SC)/2008 (SA-III) Dt: 14.09.2009) to Mr. D. Raghu from the University Grant Commission (UGC), New Delhi, India for financial support. We express our sincere thanks to Professor and Head for providing cassava stakes maintained at Tapioca and Castor Research Station (TCRS), Yethapur at Salem in Tamil Nadu. We are also grateful to the Professor and Head, Department of Plant Biotechnology (DPB), Centre for Plant Molecular Biology and Biotechnology (CPMBB), Tamil Nadu Agricultural University (TNAU) for providing the laboratory facilities.

\section{Compliance with Ethical Standards}

Disclosure of potential conflicts of interest : N/A

Funding:

University Grant Commission (UGC), RGNF grant (No: F. 14-2 (SC)/2008 (SAIII) Dt: 14.09.2009), New Delhi, India

Research involving Human Participants and/or Animals : N/A

Informed consent N/A

\section{References}

Antony B, Lisha VS, Palaniswami MS (2009) Evidences for transmission of Indian cassava mosaic virus through Bemisia 
tabaci - cassava biotype. Archives of Phytopathology and Plant Protection, 42(10): 922-929.

Apel K, Hirt H (2004) Reactive oxygen species: Metabolism, oxidative stress, and signal transduction. Annu Rev Plant Biol. 55: 373399.

Badri DV, Chaparro JM, Manter DK, Martinoia E, Vivanco JM (2012) Influence of ATP binding cassette transporters in root exudation of phytoalexins, signals, and in disease resistance. Frontiers in plant science. 3: 1-17.

Baldwin JE, Adlington RM, Crouch NP, Pereira IAC (1993) Incorporation of 180 labeled water into oxygenated products produced by the enzyme deacetoxy deacetylcephalosporin C-synthase. Tetrahedron. 49:7499-7518.

Bargen SV, Salchert K, Paape M, Piechulla B, Kellmann JW (2001) Interactions between the tomato spotted wilt virus movement protein and plant proteins showing homologies to myosin, kinesin and DnaJlike chaperones. Plant Physiol Biochem. 39(12): 1083-1093.

Barthet MM, Khidir W (2007) Hilu expression of matk: functional and evolutionary implications. American J Bot. 94(8): 14021412.

Baumgartner BJ, Rapp JC, Mullet JE (1993) Plastid genes encoding the transcription/translation apparatus are differentially transcribed early in barley (Hordeum vulgare) chloroplast development. Plant Physiol 1993, 101: 781791.

Bendahmane A, Farnham G, Moffett P, Baulcombe DC (2002) Constitutive gain-offunction mutants in a nucleotide binding site-leucine rich repeat protein encoded at the Rx locus of potato. Plant J. 32: 195-204.

Blum H, Beier H, Gross HJ (1987) Improved silver staining of plant proteins, RNA and DNA in polyacrylamide gels. Electrophoresis. 8: 93-99.

Bradbury JH, Holloway WD (1988) Chemistry of tropical roots. 135-138.

Bradford MM (1976) A rapid and sensitive method for the quantification of microgram of proteins using the principles of protein- dye binding. Anal Biochem. 72: 248-254.

Cabral GB, Carvalho LJCB (2001) Analysis of proteins associated with storage root formation in cassava using two-dimensional gel electrophoresis. Rev Bras Fisiol Veg. 13: 41-48.

Caverzan A, Passaia G, Rosa SB, Ribeiro CW, Lazzarotto F, Margis-Pinheiro M (2012) Plant responses to stresses: Role of ascorbate peroxidase in the antioxidant protection Genet Mol Biol. 35(4): 10111019.

Ceballos H, Iglesias CA, Perez JC, Dixon AGO (2004) Cassava breeding: opportunities and challenges. Plant Molecular Biology. 56: 503-516.

Chang IF, Miranda KS, Pan S, Serres J (2005) Proteomic Characterization of Evolutionarily Conserved and Variable Proteins of Arabidopsis Cytosolic Ribosomes. Plant Physiol. 137: 848-862.

Chivasa S, Tome DFA, Hamilton JM, Slabas AR (2011) Proteomic Analysis of Extracellular ATP-Regulated Proteins Identifies ATP Synthase Subunit as a Novel Plant Cell Death Regulator. Mol Cell Proteomics. 10: $1-13$.

Cho UH, Seo NH (2005) Oxidative stress in Arabidopsis thaliana exposed to cadmium is due to hydrogen peroxide accumulation, Plant Science. 168(1): 113-120.

Clay NK, Adio AM, Denoux C, Jander G, Ausubel FM (2009) Glucosinolate metabolites required for an Arabidopsis innate immune response. Science. 323: 95101.

Cock JH (1985) Cassava: A basic energy source in the tropics. In Cock JH, Reyes JA (eds), Cassava: Research, Production and Utilization. UNDP CIAT.

Dabrowska G, Kata1 A, Goc1 A (2007) Magdalena szechyńska-hebda2, and edyta skrzypek2 characteristics of the plant ascorbate peroxidase family Acta biologica cracoviensia Series Botanica. 49(1): 7-17.

De Souza CRB, Carvalho LJCB, De Almeida ERP, Gander ES (2002) Identification of cassava root protein genes. Plant Foods for Human Nutrition. 57: 353-363.

Deng D, McGrath PF, Robinson DJ, Harrison BD (1994) Detection and differentiation of 
whitefly-transmitted geminiviruses in plants and vector insects by the polymerase reaction with degenerate primers. Ann Appl Biol. 125: 327-336.

Ding B, Itaya A, Qi YJ (2003) Symplasmic protein and RNA traffic: Regulatory points and regulatory factors. Current Opinion in Plant Biology 2003, 6: 596-602.

Ellis RJ (1990) Molecular chaperones: the plant connection. Science. 250: 954-959.

El-Sharkawy MA (2004) Cassava biology and physiology. Plant Mol Biol. 56(4): 481-501.

Ems SC, Morden CW, Dixon CK, Wolfe KH, Depamphilis CW, Palmer JD (1995) Transcription, splicing and editing of plastid RNAs in the nonphotosynthetic plant Epifagus virginiana. Plant Mol Biol. 29: 721-733.

Foyer CH, Noctor G (2005) Redox homeostasis and antioxidant signaling: A metabolic interface between stress perception and physiological responses. Plant Cell. 17: 1866-1875.

Gao Y, Xu Z, Jiao F, Yu H, Xiao B, Li Y, Lu X (2010) Cloning, structural features, and expression analysis of resistance gene analogs in tobacco. Mol. Biol. Rep. 37(1): 345-354.

Gbadegesin MA, Wills MA, Beeching JR (2008) Diversity of LTR-retrotransposons and Enhancer/Suppressor Mutator-like transposons in cassava (Manihot esculenta Crantz). Mol Genet Genomics. 280: 305317.

Gegios A, Amthor R, Maziya-Dixon B, Egesi C, Mallowa S, Nungo R, Gichuki S, Mbanaso A, Manary MJ (2010) Children consuming cassava as a staple food are at risk for inadequate zinc, iron, and vitamin A intake. Plant Foods for Human Nutrition. 65: 6470.

Golecki B, Schulz A, Thompson GA (1999) Translocation of structural $P$ proteins in the phloem. The Plant Cell. 11: 127-140.

Herrera R, Krier C, Lalanne C, Ba EIHM, Stokes A, Salin F, Fourcaud T, Claverol S, Plomion C (2010) Keeping the stem straight: a proteomic analysis of maritime pine seedlings undergoing phototropism and gravitropism. BMC Plant Biology. 10:217.

Hoagland DR, Arnon DI (1950) The water-culture method for growing plants without soil. Berkley: University of California the Agricultural Experiment Station circular. 347.

Howeler R, Lutaladio N, Thomas G (2013) Save and grow: cassava - a guide to sustainable production intensification. Rome, Italy: Food and Agriculture Organization of the United States of America.

Inze D, Montagu MV (1995) Oxidative stress in plants. Current Opinion in Biotechnol. 6:153-158.

Jagadish SVK, Muthurajan R, Oane R, Wheeler TR, Heuer S, Bennett J (2010) Physiological and proteomic approaches to address heat tolerance during anthesis in rice (Oryza sativa L.). Journal of Experimental Botany. 61: 143-156.

Jones JDG (2001) Putting knowledge of plant disease resistance genes to work. Curr Opin Plant Biol. 4: 281-287.

Klein RR, Mullet JE (1990) Light-induced transcription of chloroplast genes. psbA transcription is differentially enhanced in illuminated barley. J Biol Chem. 265: 1895-1902.

Klein RR (1991) Regulation of light-induced chloroplast transcription and translation in eight-day-old dark-grown barley seedlings. Plant Physiol. 97: 335-342.

Kobae Y, Sekino T, Yoshioka H, Nakagawa T, Martinoia E, Maeshima M (2006) Loss of AtPDR8, a plasma membrane ABC transporter of Arabidopsis thaliana, causes hypersensitive cell death upon pathogen infection. Plant Cell Physiol. 47: 309-318.

Kuniak E, Sklodowska M (2001) Ascorbate, glutathione and related enzymes in chloroplasts of tomato leaves infected by Botrytis cinerea. Plant Science. 160(4): 723-731.

Li K, Zhu W, Zeng K, Zhang Z, Ye J, Ou W, Rehman S, Heuer B, Chen S (2010) Proteome characterization of cassava (Manihot esculenta Crantz) somatic embryos, plantlets and tuberous roots. Proteome Sci. 8: 10. (http://www. proteomesci.com/content/8/1/10).

Liao HL, Burns JK (2012) Gene expression in Citrus sinensis fruit tissues harvested from huanglongbing-infected trees: comparison 
with girdled fruit. J Exp Bot. 63(8):33073319.

Lipka V, Dittgen J, Bednarek P, Bhat R, Wiermer M, Stein M, Land- tag J, Brandt W, Rosahl S, Scheel D, Llorente F, Molina A, Parker J, Somerville S, Schulze-Lefert P (2005) Pre and post invasion defences both contribute to non- host resistance in Arabidopsis. Science. 310: 1180-1183.

Liu J, Zheng Q, Ma Q, Gadidasu KK, Zhang P (2011) Cassava genetic transformation and its application in breeding. Journal of Integrative Plant Biology. 53: 552-569.

Lloyd MD, Merritt KD, Lee V, Sewell TJ, Whason B, Baldwin JE, Schofield CJ, Elson SW, Baggaley KH, Nicholson NH (1999) Product substrate engineering by bacteria: studies on clavaminate synthase, a trifunctional dioxygenase. Tetrahedron. 55:10201-10220.

Lucas WJ (1999) Plasmodesmata and the cell-tocell transport of proteins and nucleoprotein complexes. J. of Exp. Bot. 50: 979-987.

Mann C (1997) Reseeding the green revolution. Science. 277: 1038-1043.

Mayer MP (2005) Recruitment of Hsp70 chaperones: a crucial part of viral survival strategies. Rev Physiol Biochem Pharmacol. 53: 1-46.

Mehlhorn H, Lelandais M, Korth HG Foyer CH (1996) Ascorbate is the natural substrate for plant peroxidases. FEBS Letters. 378: 203206.

Mitprasat M, Roytrakul S, Jiemsup S, Boonseng O, Yokthongwattana K (2011) Leaf proteomic analysis in cassava (Manihot esculenta, Crantz) during plant development, from planting of stem cutting to storage root formation. Planta. 233: 1209-1221.

Mittler R (2002) Oxidative stress, antioxidants and stress tolerance. Trends Plant Sci. 7: 405-410.

Muller KF, Borsch T, Hilu KW (2006) Phylogenetic utility of rapidly evolving DNA at high taxonomical levels: contrasting matK, trnT-F and $\mathrm{rbcL}$ in basal angiosperms. Molecular Phylogenetics and Evolution. 41: 99-117.

Nwugo CC, Lin H, Duan Y, Civerolo E (2013) The effect of 'Candidatus Liberibacter asiaticus' infection on the proteomic profiles and nutritional status of presymptomatic and symptomatic grapefruit (Citrus paradisi) plants. BMC Plant Biol. 13: 59.

Oparka KJ (2004) Getting the message across: how do plant cells exchange macromolecular complexes? Trends in Plant Science. 9: 33-41.

Patil BL, Legg JP, Kanju E, Fauquet CM (2015) Cassava brown streak disease: a threat to food security in Africa. Journal of General Virology. 96 (Pt 5): 956-968.

Pellinen RI, Minna-Sisko K, Tauriainen AA, Palva ET, Kangasja RVIJ (2002) Hydrogen peroxide activates cell death and defense gene expression in birch. Plant Physiology. 130: 549-560.

Plaxton W, Podesta F (2006) The functional organization and control of plant respiration. CRC Crit Rev Plant Sci. 25: 159-198.

Pnueli L, Liang H, Rozenberg M, Mittler R (2003) Growth suppression, altered stomatal responses, and augmented induction of heat shock proteins in cytosolic ascorbate peroxidase (Apx1)- decient Arabidopsis plants, Plant Journal. 34(2):187-203.

Prathibha S, Nambisan B, Leelamma S (1995) Enzyme inhibitors in tuber crops and their thermal stability. Plant Food Hum Nutr. 48: 247-257.

Prescott AG, John P (1996) Dioxygenases: molecular structure and role in plant metabolism. Annu Rev Plant Physiol Plant Mol Biol. 47:245-271.

Prescott AG (1993) A dilemma of dioxygenases (or where biochemistry and molecularbiology fail to meet). J Exp Bot. 44:849861.

Puonti-Kaerlas J (1998) Cassava biotechnology. Biotech, Genet Enging Rev. 15: 329-364.

Pushkar Y, Yano J, Sauer K, Boussac A, Yachandra VK (2008) Structural changes in the $\mathrm{Mn} 4 \mathrm{Ca}$ cluster and the mechanism of photosynthetic water splitting. Proc Natl Acad Sci USA. 105(6): 1879-1884.

Raghu D, Senthil N, Raveendran M, Karthikayan G, Pugalendhi L, Nageswari K, Mohan C (2013) Molecular Studies on the Transmission of Indian Cassava Mosaic 
Virus (ICMV) and Sri Lankan Cassava Mosaic Virus (SLCMV) in Cassava by Bemisia tabaci and Cloning of ICMV and SLCMV Replicase Gene from Cassava. Mol Biotechnol. 53(2): 150-158.

Raghu D, Senthil N, Raveendran M, Karthikayan G, Pugalendhi L, Nageswari K, Janavi GJ, Jana Jeevan R, Mohan C (2011) Eradication of cassava mosaic disease from high yielding Indian cassava clone through apical meristem-tip culture for small farmers. Proc. International Conference on Preparing Agriculture for Climate Change, February 6-8, Crop Improvement Society of India, Punjab Agricultural University, Ludhiana, Punjab. pp. 259.

Raghu D, Senthil N, Raveendran M, Karthikayan G, Pugalendhi L, Nageswari K, Jana Jeevan R, Mohan C (2011) Molecular studies on cassava mosaic virus transmission in cassava by Bemisia tabaci (Homoptera: Aleyrodidae). Proc. 2nd Indo-Swiss Collaboration in Biotechnology (ISCB) Symposium, March 10\&11, Symposium Hall, NASC Complex, New Delhi. pp. 5051.

Sagaram M, Burns JK (2009) Leaf chlorophyll fluorescence parameters and huanglongbing. J Amer Soc Hort Sci. 134(2): 194-201.

Salekdeh GH, Siopongco J, Wade LJ, Ghareyazie B, Bennett J (1989) Proteomic analysis of rice leaves during drought stress and recovery. Proteomics 2002, 2: 11311145.Sambrook J, Fritsch EF, Maniatis T: Molecular cloning: A Laboratory Manual. (Cold Spring Harbor Laboratory, Cold Spring Harbor, New York).

Scholthof HB (2005) Plant virus transport: motions of functional equivalence. Trends in Plant Science. 10(8): 376-382.

Sheffield J, Taylor N, Fauquet C, Chen S (2006) The cassava (Manihot esculenta Crantz) root proteome: Protein identification and differential expression. Proteomics. 6: $1588-1598$

Shewry PR (2003) Tuber storage protein. Ann Bot. 91: 755-769.

Smith and chance B (1958) Cytochromes in Plants. Annual Review of Plant Physiology. 9: 449-482.
Souza PAS, Gomes E, Compos FAP (1998) Tissue distribution and deposition pattern of a cellulosic parenchyma-specific protein from cassava roots. Braz Arch Biol Technol. 41: 1-9.

Stein M, Dittgen J, Sanchez-Rodriguez C, Hou BH, Molina A, Schulze-Lefert P, Lipka V, Somerville S (2006) Arabidopsis PEN3/PDR8, an ATP binding cassette transporter, contributes to non host resistance to inappropriate pathogens that enter by direct penetration. Plant Cell. 18: 731-746.

Stephenson K, Amthor R, Mallowa S, Nungo R, Maziya-Dixon B, Gichuki S, Mbanaso A, Manary M (2010) Consuming cassava as a staple food places children 2-5 years old at risk for inadequate protein intake, an observational study in Kenya and Nigeria. Nutrition Journal. 9: 9.

Thakur M, Sohal BS (2013) Role of Elicitors in Inducing Resistance in Plants against Pathogen Infection: A Review. ISRN Biochemistry. 1-10.

Tillich M, Funk HT, Schmitz-Linneweber C, Poltnigg P, Sabater B, Martin M, Maier RM (2005) Intra editing of plastid RNA in Arabidopsis thaliana ecotypes. Plant J. 43: 708-715.

Uarrota VG, Nunes Eda C, Peruch LA, Neubert Ede O, Coelho B, Moresco R, Dominguez MG, Sanchez T, Melendez JL, Dufour D (2016) Toward better understanding of postharvest deterioration: biochemical changes in stored cassava (Manihot esculenta Crantz) roots. Food Sciences and Nutrition. 4: 409-422.

Vanderschuren H, Nyaboga E, Poon JS, Baerenfaller K, Grossmann J, HirschHoffmann M, Kirchgessner N, Nanni P, Gruissem W (2014) Large-scale proteomics of the cassava storage root and identification of a target gene to reduce postharvest deterioration. Plant Cell. 26: 1913-1924.

Vanlerberghe GC, McIntosh L (1997) Alternative oxidase: from gene to function. Annu Rev Plant Physiol Plant Mol Biol. 48: 703-734.

Vogel J, Hubschmann T, Borner T, Hess WR (1997) Splicing and intron-internal RNA editing of trnK-matK transcripts in barley 
plastids: support for MatK as an essential splicing factor. J Mol Biol. 270: 179-187.

Whitham SA, Wang Y (2004) Roles for host factors in plant viral pathogenicity. Current Opinion in Plant Biol. 7(4): 365-37.

Wolf PG, Rowe CA, Sinclair RB, Hasebe M (2003) Complete nucleotide sequence of the chloroplast genome from a leptosporangiate fern, Adiantum capillus-veneris L. DNA research. 10: 59-65.

Xiao WK, Xu ML, Zhao JR, Wang FG, Li JS, Dai JR (2006) Genome-wide isolation of resistance gene analogs in maize (Zea mays
L.). Theor Appl Genet. 113: 63-72.

Yan S, Tang Z, Su W, Sun W (2005) Proteomic analysis of salt stress responsive proteins in rice root. Proteomics. 5: 235-44.

Zhu H, Dardick CD, Beers EP, Callanhan AM, Xia R, Yuan R (2011) Transcriptomics of shading-induced and NAAinduced abscission in apple (Malus domestica) reveals a shared pathway involving reduced photosynthesis, alterations in carbohydrate transport and signaling and hormone crosstalk. BMC Plant Biol. 11:138.

\section{How to cite this article:}

Raghu Duraisamy, Senthil Natesan, Raveendran Muthurajan, Karthikayan Gandhi, Pugalendhi Lakshmanan, Janavi Gnanaguru Janaky, Nageswari Karuppusamy and Mohan Chokkappan. 2019. Proteomic Analysis of Cassava Mosaic Virus (CMV) Responsive Proteins in Cassava Leaf. Int.J.Curr.Microbiol.App.Sci. 8(04): 2988-3005. doi: https://doi.org/10.20546/ijcmas.2019.804.345 